\title{
Science as a Culture in Contemporary Japan
}

\author{
Jun-ichi KYOGOKU \\ Tokyo University
}

Fellow reporters of the Conference seem to be either philosophers or scientists in the stricter sense of word. But, professionally, I am neither a philosopher nor a scientist. My speciality is the study of government and politics, especially the study of political behavior of the Japanese people. Philosophy, science, and philosophy of science is not my field. I am not in a position to talk on the professionally philosophical aspects of the topic of the Conference. Instead, I am going to make a comment on the cultural or political aspect of "man in the scientific age".

\section{II}

Science is a culture, that is, it is a way of life with clear-cut institutions, behavior patterns and a value system. But science as a culture is not shared by every human being living on the earth in 1962. Rather, science is one of many sub-cultures in the contemporary world. Even in the so-called "advanced and developed" countries, it is not a common basic culture, that is, it is not a culture generally accepted and approved.

There seems, however, to be emerging a new society in which science is to be the common basic culture of all people. There science would not be a subculture any more. Rather, I should say that a new stage in the development of human social conditions is arriving. The arrival of agriculture once meant a radical transformation in human social conditions. It made possible for the human being on the globe to establish settled and organized-undeniably aristocratically organized-societies with their institutions, behavior patterns and value systems. Agrarian society had their own virtue and vice, dignity and misery, beauty and ugliness. Now, in the new stage of human history, science and technology are going to develop a new type of societies, industrialized, affiuent and much more democratically organized societies. Needless to say, industrialization supported by science and technology is not omnipotent. Many human problems, especially problems related to the individual, personal and existential conditions of humanity will stay on. But, so far as the human social conditions are concerned, industrialization is the very hope of the poor people in every country and throughout the world.

The impact of changing basic cultures and social patterns has made the division and difference of orientations among the people quite clear. Firstly, there 
are reactionary groups spearheaded by the Luddite literati. They strongly insist that the culture supported by agriculture is the best one in the human history. Secondly, there are radical, if not revolutionary, groups represented by quite a few scientists who assert that the industrialization is the only way to do the human miseries away. Thirdly, there are a great majority of men of affairs, that is, politicians and administrators, business and labor people, and engineers. They are conservative in the sense that they want a slow and smooth change without any serious damage to their vested interests.

Frankly, these points are not new. They are already voiced by many people. The latest example is Sir Charles Percy Snow.

\section{III}

I would like to speak a little more about the Japanese scene. Japan is a kind of pilot plant for the rapid change from agrarian to industrial society. She is also a pilot plant for the successful containment of science as a culture into a restricted sector of the society.

Roughly a century ago under the pressure of the Western impact Japan felt the necessity of reorganizing herself politically and culturally. After decades of birth pain modern unified Japan emerged. Modern Japan needed the modern industry and the modern military power on the one hand and the political integration and unity on the other. Modern industry was to be aided by science as a culture. Political integration was to based on the political orthodoxy deeply rooted in the agrarian culture. It was a "have and eat a cake" kind of business. It was, of course, impossible to attain both goals at once. Both goals had to suffer and science suffered much worse.

Japan had to import science. It was necessary. But she could not tolerate the influx of the science as a culture leniently. Science had to be treated as finished goods which were portable. Many observers concur in their comments that Japan brought in science as a kind of cut flowers but she did not like to nurse them domestically. Science as a culture was thus restricted by "partial incorporation". Science as a sub-culture was able to work quite effectively in a very limited sector, which was always separated from the more basic - and nativecultures of Japan. Let me give only ene example. World War II saw the birth of cybernetics and operations research. But, they did not begin in Japan, although with quite a few distinguished Japanese scientists they could have begun. Japanese society appearently failed to build a nation-wide greenhouse for the science.

Still now we have institutions of keeping science in restricted sector. In college there are a long established tradition of providing two kinds of courses to students. The one is the L-course for the humanities and social studies students who are to become either literati or men of affairs. Yet, L-course gives very meager instruction in mathematics and science with the approval of the scientists. The other course is S-course for science, technology and medical students. Specialization is necessary and inevitable. The trouble is the prejudice that the specialization of this kind is self-evidently right. And it is the prejudice which is 
commonly held in both humanities and science sectors. Both groups are not unhappy with the arrangement. Graduates from L-course can believe that not to understand mathematics and science is precisely the virtue of a "real" human being. Scientist can look down upon the humanities as imbecile barbarians because of their ignorance. Thus, the Japanese house of intellect has long been devided. Since graduates from L-course have been much greater in number-seven to three -and much more influential socially and politically, science has been and still is kept in a very restricted sector. Even the recent educational efforts of putting much more emphasis on science was, as matter of fact, carried through along the the line of separating L- and S-course students much earlier. This was approved and accepted without any investigation and reconsideration on the future of Japan. Although the official goal was to help develop the technological innovation, it would very easily lead to the freezing of education, basic culture and social pattern, to the fortifying of the vested interests and, thus, to the obstruction of much more smooth change. Instead, we need such educational reorganization for the coming generation as adaptive and conducive to the cultural change.

IV

For modern Japan the political integration was of prime importance. Agrarian basic culture had to be guarded very jealously. There was established a political orthodoxy, which finally lead to the ultra-nationalism. What is important is that a political orthodoxy is poisonous. It leads to the idolatry of existing political ideology, institutions, etc. Since the contemporary set up of human social conditions is idolized absurdly and fervently, the participants of the political system very easily lose the perspective to the future, to the new true future. No future in perspective, people begin to believe that the human affairs consist of the mechanical administration of the deified eternal arrangements. In other words, the human ability of conducting the "political" art, the art of the possible, begins to atrophy. It is the human misery. Up to 1945 under one type of political orthodoxy Japan suffered from the atrophy of the political ability. After 1945 Japan has replaced the older orthodoxy by a new one. Still she seems to be suffering from the underdevelopment of political ability. Daily we feel many examples of political incapacity. What Japan badly needs is the transfusion of the blood of the future-orientedness and originality-orientedness from the science as a culture in order to attain her maturation. Here is one of the many chances for the science to make a cultural or political contribution.

There are many other chances. The Japanese government and politics are not well-advised nor well-guided by science. It is an undeniable fact. And it is a serious problem. The other trouble is that we are now seeing the popular unrest and agitation caused by the changing basic culture and social pattern. Japanese people are now sensing the advent of the new culture based on science and technology. In some quarters there are sincere aspiration. In business, industry and even in agriculture many formal and informal seminars and study meetings are held. People get together, listen to the speakers and discuss. Very often 
rosy hope are shared by the attendants. But in other quarters, there are insecurity and even desperate frustration. Sometimes meetings and discussion arouse the dormant insecurity. Quite a few people sense the change but do not know how to proceed, nor they are told. They may hear the talks by rear-guard Luddites about the machine age and $\operatorname{cog}$-wheel man, but they are not provided with effective political leadership. At least some of them do feel in that way. Insecurity is fairly abundant. What is necessary is not only the educational reorganization for the coming generations, but also the political leadership, that is, such de-education and re-education of the grown-up public as adaptive and conducive to the change. Change in basic culture and social pattern can every easily lead to unbearable human misery and indignity. What is most important is to search for the course of change with less misery and less anomie. In other words, the bold imagination and the tender heart are badly needed. And, so far as history shows, these two qualities have been best provided by science as a culture. 